\title{
Evaluation of Tritium Content and Release from Pressurized Water Reactor Fuel Cladding
}

Fuel Cycle Research \& Development

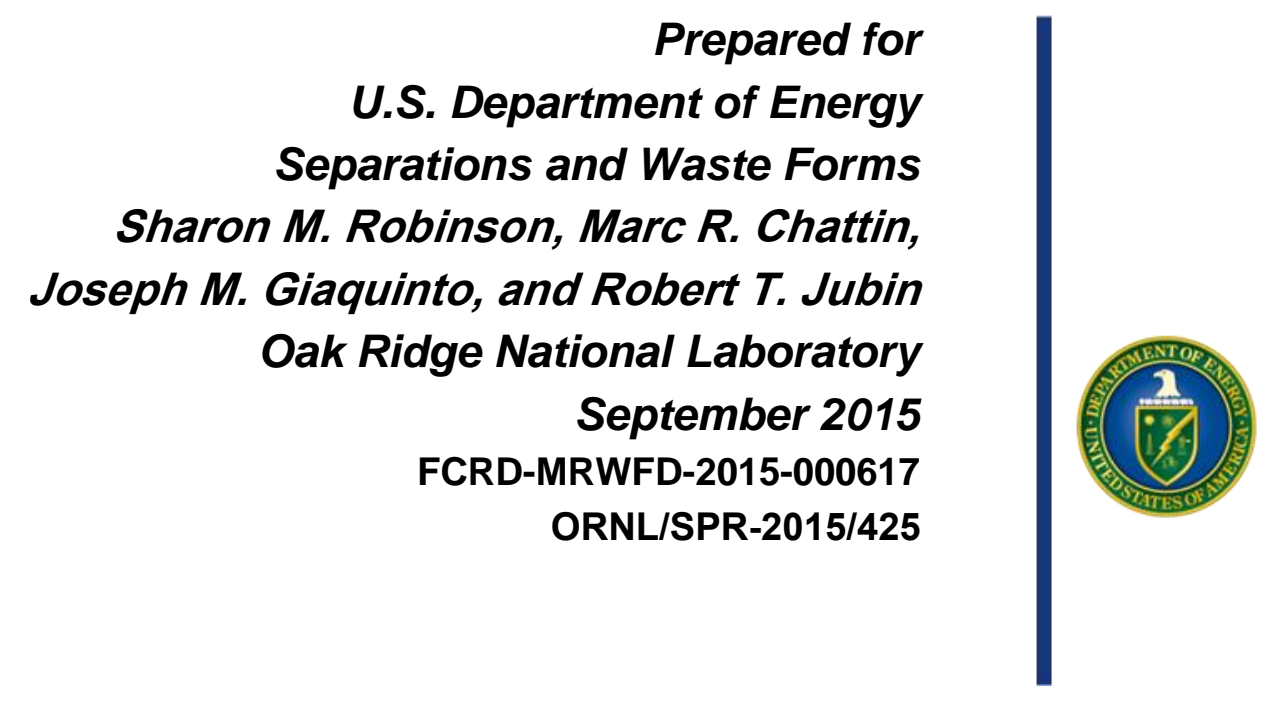




\section{DISCLAIMER}

This information was prepared as an account of work sponsored by an agency of the U.S. Government. Neither the U.S. Government nor any agency thereof, nor any of their employees, makes any warranty,

expressed or implied, or assumes any legal liability or responsibility for the accuracy, completeness, or usefulness, of any information, apparatus, product, or process disclosed, or represents that its use would not infringe privately owned rights. References herein to any specific commercial product, process, or service by trade name, trade mark, manufacturer, or otherwise, does not necessarily constitute or imply its endorsement, recommendation, or favoring by the U.S. Government or any agency thereof. The views and opinions of authors expressed herein do not necessarily state or reflect those of the U.S. Government or any agency thereof. 


\section{SUMMARY}

It is expected that tritium pretreatment will be required in future reprocessing plants to prevent the release of tritium to the environment (except for long-cooled fuels). To design and operate future reprocessing plants in a safe and environmentally compliant manner, the amount and form of tritium in the used nuclear fuel (UNF) must be understood and quantified. Tritium in light water reactor (LWR) fuel is dispersed between the fuel matrix and the fuel cladding, and some tritium may be in the plenum, probably as tritium labelled water (THO) or $\mathrm{T}_{2} \mathrm{O}$. In a standard processing flowsheet, tritium management would be accomplished by treatment of liquid streams within the plant. Pretreating the fuel prior to dissolution to release the tritium into a single off-gas stream could simplify tritium management, so the removal of tritium in the liquid streams throughout the plant may not be required. The fraction of tritium remaining in the cladding may be reduced as a result of tritium pretreatment.

Since Zircaloy® cladding makes up roughly $25 \%$ by mass of UNF in the United States, processes are being considered to reduce the volume of reprocessing waste for Zircaloy® clad fuel by recovering the zirconium from the cladding for reuse. These recycle processes could release the tritium in the cladding.

For Zircaloy-clad fuels from light water reactors, the tritium produced from ternary fission and other sources is expected to be divided between the fuel, where it is generated, and the cladding. It has been previously documented ${ }^{1}$ that a fraction of the tritium produced in uranium oxide fuel from LWRs can migrate and become trapped in the cladding. Estimates of the percentage of tritium in the cladding typically range from $0-96 \%$. There is relatively limited data on how the tritium content of the cladding varies with burnup and fuel history (temperature, power, etc.) and how pretreatment impacts its release.

To gain a better understanding of how tritium in cladding will behave during processing, scoping tests are being performed to determine the tritium content in the cladding pre- and post-tritium pretreatment. Samples of Surry-2 and H.B. Robinson pressurized water reactor cladding were heated to $1100-1200^{\circ} \mathrm{C}$ to oxidize the zirconium and release all of the tritium in the cladding sample. Cladding samples were also heated within the temperature range of $480-600^{\circ} \mathrm{C}$ expected for standard air tritium pretreatment systems, and to a slightly higher temperature $\left(700^{\circ} \mathrm{C}\right)$ to determine the impact of tritium pretreatment on tritium release from the cladding.

The tritium content of the Surry-2 and H.B. Robinson cladding was measured to be $\sim 234$ and $\sim 500 \mu \mathrm{Ci} / \mathrm{g}$, respectively. Heating the Surry- 2 cladding at $500^{\circ} \mathrm{C}$ for $24 \mathrm{~h}$ removed $\sim 0.2 \%$ of the tritium from the cladding, and heating at $700^{\circ} \mathrm{C}$ for $24 \mathrm{~h}$ removed $\sim 9 \%$. Heating the H.B. Robinson cladding at $700^{\circ} \mathrm{C}$ for $24 \mathrm{~h}$ removed $\sim 11 \%$ of the tritium. When samples of the Surry- 2 and H.B. Robinson claddings were heated at $700^{\circ} \mathrm{C}$ for $96 \mathrm{~h}$, essentially all of the tritium in the cladding was removed. However, only $\sim 3 \%$ of the tritium was removed when a sample of Surry- 2 cladding was heated at $600^{\circ} \mathrm{C}$ for $96 \mathrm{~h}$.

These data indicate that the amount of tritium released from tritium pretreatment systems will be dependent on both the operating temperature and length of time in the system. Under certain conditions, a significant fraction of the tritium could remain bound in the cladding and would need to be considered in operations involving cladding recycle. 


\section{CONTENTS}

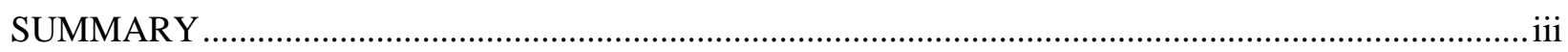

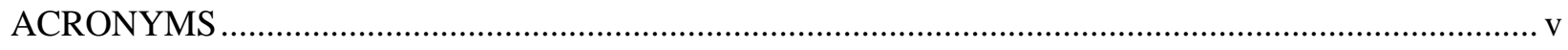

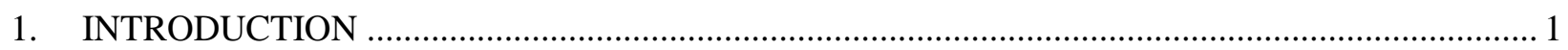

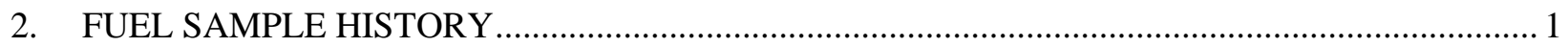

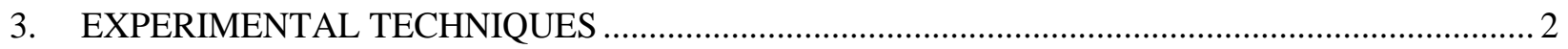

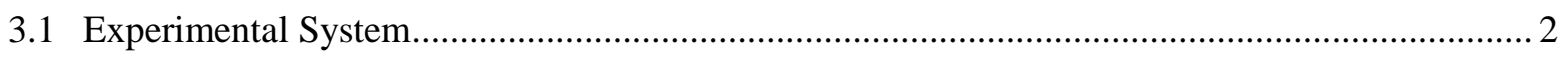

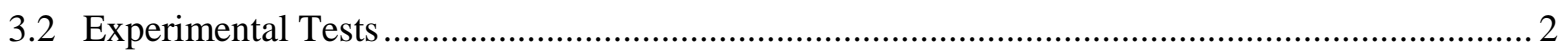

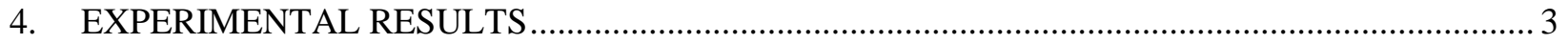

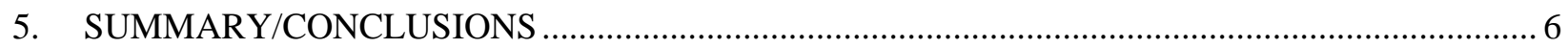

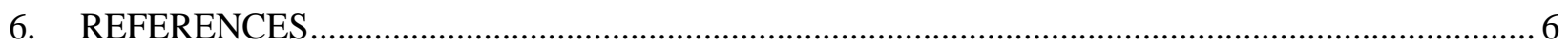




\section{ACRONYMS}

$\begin{array}{ll}\text { CETE } & \text { Coupled End-To-End } \\ \text { GWd/MTU } & \text { gigawatt day per metric tonne uranium } \\ \text { LWR } & \text { light water reactor } \\ \text { PWR } & \text { pressurized water reactor } \\ \text { UNF } & \text { used nuclear fuel }\end{array}$





\section{EVALUATION OF TRITIUM CONTENT AND RELEASE FROM SURRY-2 FUEL CLADDING}

\section{INTRODUCTION}

Zircaloy® cladding makes up roughly $25 \%$ by mass of used nuclear fuel (UNF) in the United States. In the future, reprocessing may be the option of choice for disposition of UNF from light water reactors (LWRs). Treatment options for Zircaloy cladding include recycling to recover the significant cost of the zirconium and eliminate costs associated with the disposal of transuranic-contaminated Zircaloy®. If LWR fuel is reprocessed and the fuel is dissolved without tritium pretreatment, the tritium in the cladding will remain bound to the cladding. If tritium pretreatment is included in the flow sheet, some portion of the tritium in the cladding may be released along with the tritium from the fuel matrix. To design and operate reprocessing plants in a safe and environmentally compliant manner, the amount and form of tritium in the UNF must be understood and quantified.

Estimates of the percentage of tritium originally in the fuel rod that is retained in the cladding typically range from $0-96 \%$. A single sample of post-tritium pre-treated cladding was analyzed as part of the Coupled End-To-End (CETE) project, and no tritium was detected. This single data point was not a definitive test, but the results warranted additional investigation since it indicated that tritium pretreatment could potentially eliminate the presence of tritium in the zirconium recycle step. The present study was undertaken to understand how tritium pretreatment at standard air tritium pretreatment conditions (480 to $600^{\circ} \mathrm{C}$ ) affects the tritium content in the Zircaloy ${ }^{\circledR}$ cladding and the extent to which the tritium content could be reduced with modest increases in the tritium pretreatment temperature. Scoping tests are being performed to determine the tritium content of pre- and post-tritium pretreated cladding.

\section{FUEL SAMPLE HISTORY}

Tests were performed on cladding from fuel rods from Surry and H.B. Robinson pressurized water reactors (PWR).

The H.B. Robinson fuel rod contained $\mathrm{UO}_{2}$ enriched to $2.9 \mathrm{wt} \%{ }^{235} \mathrm{U}$. It was discharged from the reactor in 1995, and the average burnup was 63-67 gigawatt day per metric tonne uranium (GWd/MTU). The cladding was Zircaloy-4, which has a composition of $\sim 98 \%$ zirconium, $1.8 \%$ tin, and small fractions of nickel and iron. Samples of this fuel rod had previously been defueled by mechanically removing the fuel followed by leaching in nitric acid. The defueled cladding was cut into segments approximately $6 \mathrm{~mm}$ in length. These were used in tests to determine the material's tensile strength using standard loop tensile testing methods. This is a mechanical test that does not involve heating of the materials, and these cladding samples were then used in tests performed in this study to quantify tritium content.

Tests were also performed on cladding from a fuel rod from the Surry-2 PWR. The fuel rod from the Surry-2 PWR contained $\mathrm{UO}_{2}$ enriched to $3.1 \mathrm{wt} \%$. It was discharged from the reactor in 1981, and the average burnup was $36 \mathrm{GWd} / \mathrm{MTU}$. The cladding was Zircaloy-4. Samples of the fuel rod were defueled and cut into segments $\sim 5 \mathrm{~mm}$ in length to test for tritium content. 


\section{EXPERIMENTAL TECHNIQUES}

\subsection{Experimental System}

A high-temperature furnace was used to heat the metal clad specimens. The released tritium was transported as $\mathrm{T}_{2} / \mathrm{HT}$ and $\mathrm{HTO}$ using a carrier gas through a heated $\mathrm{CuO}$ catalyst, and subsequently the water vapor was trapped in a series of water-filled bubblers for counting using liquid scintillation.

A Carbolite Combustion Tube Furnace, Model MTT 12/38/850, was used to determine the tritium content in irradiated clads. The furnace can operate at a maximum combustion zone temperature of $1200^{\circ} \mathrm{C}$ and utilizes a copper metal catalyst in a separate heated zone for conversion of tritium gas to water for trapping. The sample carrier gas consisted of a 50:50 mixture of oxygen and nitrogen, and a 100\% oxygen gas flow was used for the catalyst zone. Three bubblers containing $\sim 60 \mathrm{~mL}$ of deionized water each were connected in series to the outlet of the furnace. The first two bubblers were routinely sampled during the tests, and the third bubbler only sampled at the end of the test. The experimental system is shown schematically in Fig. 1.

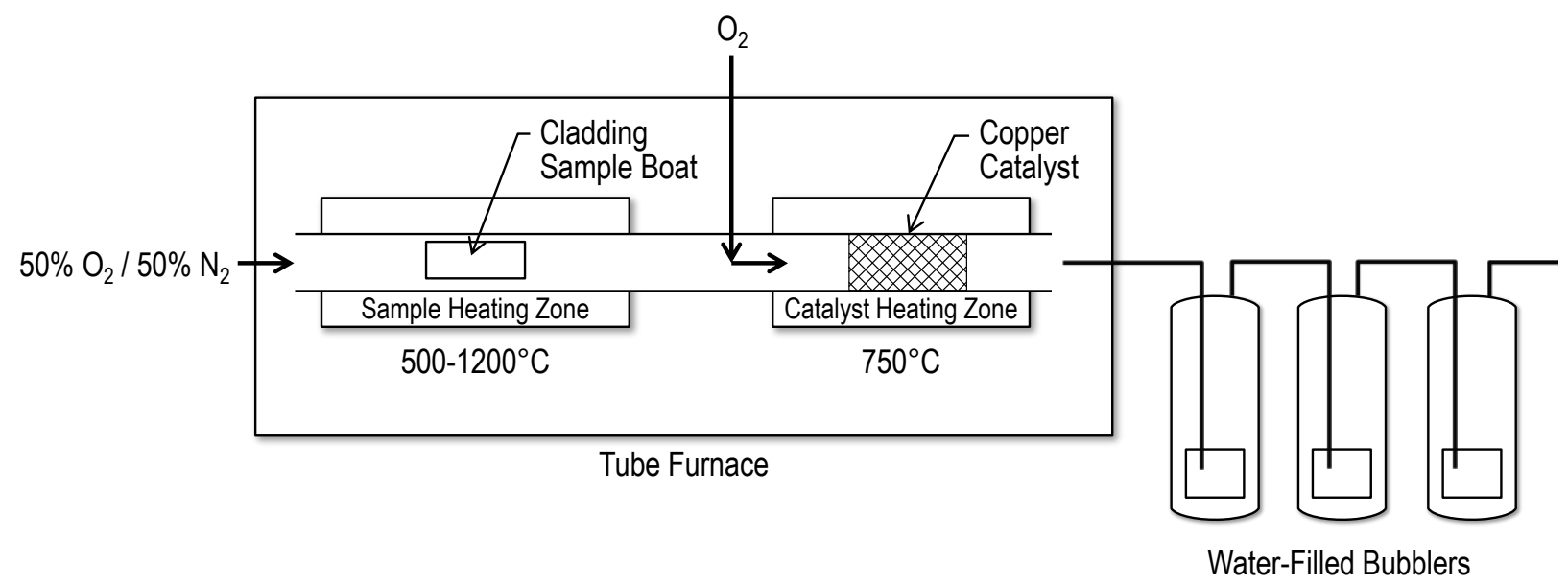

Fig. 1. Schematic of experimental test system.

\subsection{Experimental Tests}

For the experiments, 5-6 mm-wide rings of cladding were cut into three equal segments by cutting each ring at radial positions (i.e., 0, 120, and 240 degrees). The individual pieces were weighed and then subjected to different simulated tritium pretreatments. One of the samples of cladding from each ring was heated to $1100-1200^{\circ} \mathrm{C}$ to oxidize the zirconium and release all of the tritium in the cladding sample. The tritium pretreatment conditions applied to each of the remaining test segments were as follows:

- Heated at $500^{\circ} \mathrm{C}$ for $24-96 \mathrm{~h}$,

- Heated at $600^{\circ} \mathrm{C}$ for $24-96 \mathrm{~h}$,

- Heated at $700^{\circ} \mathrm{C}$ for $24-96 \mathrm{~h}$.

After simulated tritium pretreatment, the specimens were heated to $1200^{\circ} \mathrm{C}$ for $4 \mathrm{~h}$ and $1100^{\circ} \mathrm{C}$ for up to $20 \mathrm{~h}$ to totally oxidize the zirconium and release all remaining tritium. This high-temperature heating step was performed to determine the total or residual amount of tritium in the sample with the objective of closing the tritium mass balance. The initial test results indicated that the majority of the remaining tritium is released within the first $4 \mathrm{~h}$ of heating at the higher temperatures of $1100-1200^{\circ} \mathrm{C}$ required for oxidizing the samples. Thus a minimum of $4 \mathrm{~h}$ of heating at $1200^{\circ} \mathrm{C}$ was used in each test. 
These tests were performed over a two-year period. Although the results ${ }^{2}$ from the 2014 tests have been previously reported, they were also included in the data evaluation in this report.

\section{EXPERIMENTAL RESULTS}

Three rings of cladding were tested in this study: two Surry-2 rings and a ring of H.B Robinson cladding. One segment from each ring (approximately $1 / 3$ of the ring) of cladding received no simulated tritium pretreatment; it was heated to $1100-1200^{\circ} \mathrm{C}$ to oxidize the zirconium and release all of the tritium in the cladding sample. The tritium content of the two Surry- 2 cladding segments was measured to be 239 and $228 \mu \mathrm{Ci} / \mathrm{g}$ for an average of $234 \mu \mathrm{Ci} / \mathrm{g}$. The tritium content of the H.B. Robinson cladding segment was measured to be $500 \mu \mathrm{Ci} / \mathrm{g}$.

The results of tests to simulate tritium pretreatment are summarized in Table 1 . The table shows the amount of tritium released during the simulated tritium pretreatment condition $\left(500-700^{\circ} \mathrm{C}\right.$ for $\left.24-96 \mathrm{~h}\right)$, the amount of tritium released during the subsequent heating at $1100-1200^{\circ} \mathrm{C}$ which oxidized the remaining tritium in the sample, the total amount of tritium, and the percentage of tritium released during the simulated pretreatment step. The tritium pretreatment conditions of 500 and $700^{\circ} \mathrm{C}$ for $24 \mathrm{~h}$ removed $\sim 0.2$ and $9 \%$ of the tritium in the Surry-2 cladding, respectively. Similarly, heating H.B. Robinson cladding at $700^{\circ} \mathrm{C}$ for $24 \mathrm{~h}$ removed $\sim 11 \%$ of the tritium. Increasing the time the samples were exposed to heating at $700^{\circ} \mathrm{C}$ from $24 \mathrm{~h}$ to $96 \mathrm{~h}$, significantly increased to amount of tritium removed during the pretreatment step: $99.4 \%$ and $99.0 \%$ for the Surry-2 and H.B. Robinson claddings, respectively. However, only $3 \%$ of the tritium was removed from a Surry-2 sample when it was heated to only $600^{\circ} \mathrm{C}$ for $96 \mathrm{~h}$.

Table 1. Tritium in pressurized water reactor cladding

\begin{tabular}{|c|c|c|c|c|c|}
\hline $\begin{array}{c}\text { Cladding } \\
\text { sample }\end{array}$ & $\begin{array}{c}\text { Simulated } \\
\text { tritium } \\
\text { pretreatment } \\
\text { condition } \\
\left({ }^{\circ} \mathbf{C}\right)\end{array}$ & $\begin{array}{c}\text { Tritium released } \\
\text { during simulated } \\
\text { tritium } \\
\text { pretreatment } \\
(\boldsymbol{\mu} \mathbf{C i} / \mathbf{g})\end{array}$ & $\begin{array}{c}\text { Tritium in } \\
\text { cladding sample } \\
\text { during oxidation } \\
(\boldsymbol{\mu C i} / \mathbf{g})\end{array}$ & $\begin{array}{c}\text { Total tritium } \\
\text { recovered from } \\
\text { ladding sample } \\
(\boldsymbol{\mu} \mathbf{C i} / \mathbf{g})\end{array}$ & $\begin{array}{c}\text { Tritium removed } \\
\text { during simulated } \\
\text { tritium } \\
\text { pretreatment } \\
(\mathbf{\%})\end{array}$ \\
\hline $\begin{array}{c}\text { Surry-2 } \\
\text { Ring 1 }\end{array}$ & 500 for $24 \mathrm{~h}$ & 0.55 & 247.2 & 247.7 & 0.2 \\
\hline $\begin{array}{c}\text { Surry-2 } \\
\text { Ring 1 }\end{array}$ & 700 for $24 \mathrm{~h}$ & 19.2 & 201.7 & 220.9 & 8.7 \\
\hline $\begin{array}{c}\text { H.B. } \\
\text { Robinson }\end{array}$ & 700 for $24 \mathrm{~h}$ & 59.9 & 478.0 & 537.9 & 11.1 \\
\hline $\begin{array}{c}\text { Surry-2 } \\
\text { Ring 2 }\end{array}$ & 600 for $96 \mathrm{~h}$ & 7.1 & 230.8 & 237.9 & 3.0 \\
\hline $\begin{array}{c}\text { Surry-2 } \\
\text { Ring 2 }\end{array}$ & 700 for $96 \mathrm{~h}$ & 193.3 & 1.2 & 194.5 & 99.4 \\
\hline $\begin{array}{c}\text { H.B. } \\
\text { Robinson }\end{array}$ & 700 for $96 \mathrm{~h}$ & 631.8 & 6.7 & 638.5 & 99.0 \\
\hline
\end{tabular}

${ }^{1}$ Oxidation of cladding at $1100-1200^{\circ} \mathrm{C}$ to release residual tritium.

The impact of heating time and temperature on the amount of tritium released is shown in Tables 2 and 3 and Figs. 2 and 3 . They show that $\leq 20 \%$ of the tritium contained in the clad is released when heating at $500-700^{\circ} \mathrm{C}$ for tritium pretreatment for $24 \mathrm{~h}$. Essentially $100 \%$ of the tritium is released when the heating time at $700^{\circ} \mathrm{C}$ is extended to $96 \mathrm{~h}$. However, less than $3 \%$ of the tritium was released when cladding is heated at $500-600^{\circ} \mathrm{C}$ for $24-96 \mathrm{~h}$. 
Table 2. Tritium in Surry-2 cladding released as a function of heating time and temperature

\begin{tabular}{|c|c|c|c|c|c|c|c|c|c|c|c|c|}
\hline \multirow{3}{*}{ Time (h) } & \multicolumn{3}{|c|}{ Surry-2 Ring 1} & \multicolumn{3}{|c|}{ Surry-2 Ring 1} & \multicolumn{3}{|c|}{ Surry-2 Ring 2} & \multicolumn{3}{|c|}{ Surry-2 Ring 2} \\
\hline & \multirow[t]{2}{*}{$\begin{array}{c}\text { Temperature } \\
\left({ }^{\circ} \mathrm{C}\right)\end{array}$} & \multicolumn{2}{|c|}{$\begin{array}{c}\text { Cumulative } \\
\text { tritium } \\
\text { released }\end{array}$} & \multirow[t]{2}{*}{$\begin{array}{c}\text { Temperature } \\
\left({ }^{\circ} \mathrm{C}\right)\end{array}$} & \multicolumn{2}{|c|}{$\begin{array}{c}\text { Cumulative } \\
\text { tritium } \\
\text { released }\end{array}$} & \multirow[t]{2}{*}{$\begin{array}{c}\text { Temperature } \\
\left({ }^{\circ} \mathrm{C}\right)\end{array}$} & \multicolumn{2}{|c|}{$\begin{array}{c}\text { Cumulative } \\
\text { tritium } \\
\text { released }\end{array}$} & \multirow[t]{2}{*}{$\begin{array}{c}\text { Temperature } \\
\left({ }^{\circ} \mathrm{C}\right)\end{array}$} & \multicolumn{2}{|c|}{$\begin{array}{c}\text { Cumulative } \\
\text { tritium } \\
\text { released }\end{array}$} \\
\hline & & $(\mu \mathrm{Ci} / \mathrm{g})$ & $\%$ & & $(\mu \mathrm{Ci} / \mathrm{g})$ & $\%$ & & $(\mu \mathrm{Ci} / \mathrm{g})$ & $\%$ & & $(\mu \mathrm{Ci} / \mathrm{g})$ & $\%$ \\
\hline \multicolumn{13}{|c|}{ Low-Temperature Heating to Simulate Tritium Pretreatment } \\
\hline 8 & 500 & 0.29 & 0.1 & 700 & 1.9 & 0.9 & & & & & & \\
\hline 24 & 500 & 0.55 & 0.2 & 700 & 19.2 & 8.7 & 700 & 12.6 & 6.5 & 600 & 1.5 & 0.6 \\
\hline 48 & & & & & & & 700 & 192.9 & 99.2 & 600 & 2.6 & 1.1 \\
\hline 72 & & & & & & & 700 & 193.0 & 99.2 & 600 & 4.9 & 2.1 \\
\hline 96 & & & & & & & 700 & 193.3 & 99.4 & 600 & 7.1 & 3.0 \\
\hline \multicolumn{13}{|c|}{ High-Temperature Heating to Oxidize Cladding } \\
\hline 4 & 1200 & 246.7 & 99.6 & 1200 & 220.0 & 99.6 & 1200 & 193.3 & 99.4 & 1200 & 237.9 & 100 \\
\hline $20-24$ & 1100 & 246.9 & 99.7 & 1100 & 220.3 & 99.7 & & & & & & \\
\hline Final & & 247.7 & 100 & & 220.9 & 100 & & 194.5 & 100 & & 237.9 & 100 \\
\hline
\end{tabular}

Table 3. Tritium in H.B. Robinson cladding released as a function of heating time and temperature

\begin{tabular}{|c|c|c|c|c|c|c|}
\hline \multirow{3}{*}{ Time (h) } & \multicolumn{3}{|c|}{ H.B. Robinson } & \multicolumn{3}{|c|}{ H.B. Robinson } \\
\hline & \multirow[t]{2}{*}{$\begin{array}{c}\text { Temperature } \\
\left({ }^{\circ} \mathrm{C}\right)\end{array}$} & \multicolumn{2}{|c|}{$\begin{array}{c}\text { Cumulative } \\
\text { tritium } \\
\text { released }\end{array}$} & \multirow[t]{2}{*}{$\begin{array}{c}\text { Temperature } \\
\left({ }^{\circ} \mathrm{C}\right)\end{array}$} & \multicolumn{2}{|c|}{$\begin{array}{c}\text { Cumulative } \\
\text { tritium } \\
\text { released }\end{array}$} \\
\hline & & $(\mu \mathrm{Ci} / g)$ & $\%$ & & $(\mu \mathrm{Ci} / \mathrm{g})$ & $\%$ \\
\hline \multicolumn{7}{|c|}{ Low-Temperature Heating to Simulate Tritium Pretreatment } \\
\hline 8 & 700 & 11.0 & 2.0 & 700 & 8.1 & 1.3 \\
\hline 24 & 700 & 59.9 & 11.1 & 700 & 117.0 & 18.3 \\
\hline 48 & & & & 700 & 631.2 & 98.9 \\
\hline 72 & & & & 700 & 631.8 & 99.0 \\
\hline 96 & & & & & & \\
\hline \multicolumn{7}{|c|}{ High-Temperature Heating to Oxidize Cladding } \\
\hline 4 & 1200 & 536.5 & 99.7 & 1200 & 634.7 & 99.4 \\
\hline $20-24$ & 1100 & 537.7 & 100 & 1100 & 634.7 & 99.4 \\
\hline Final & & 537.9 & 100 & & 638.5 & 100 \\
\hline
\end{tabular}




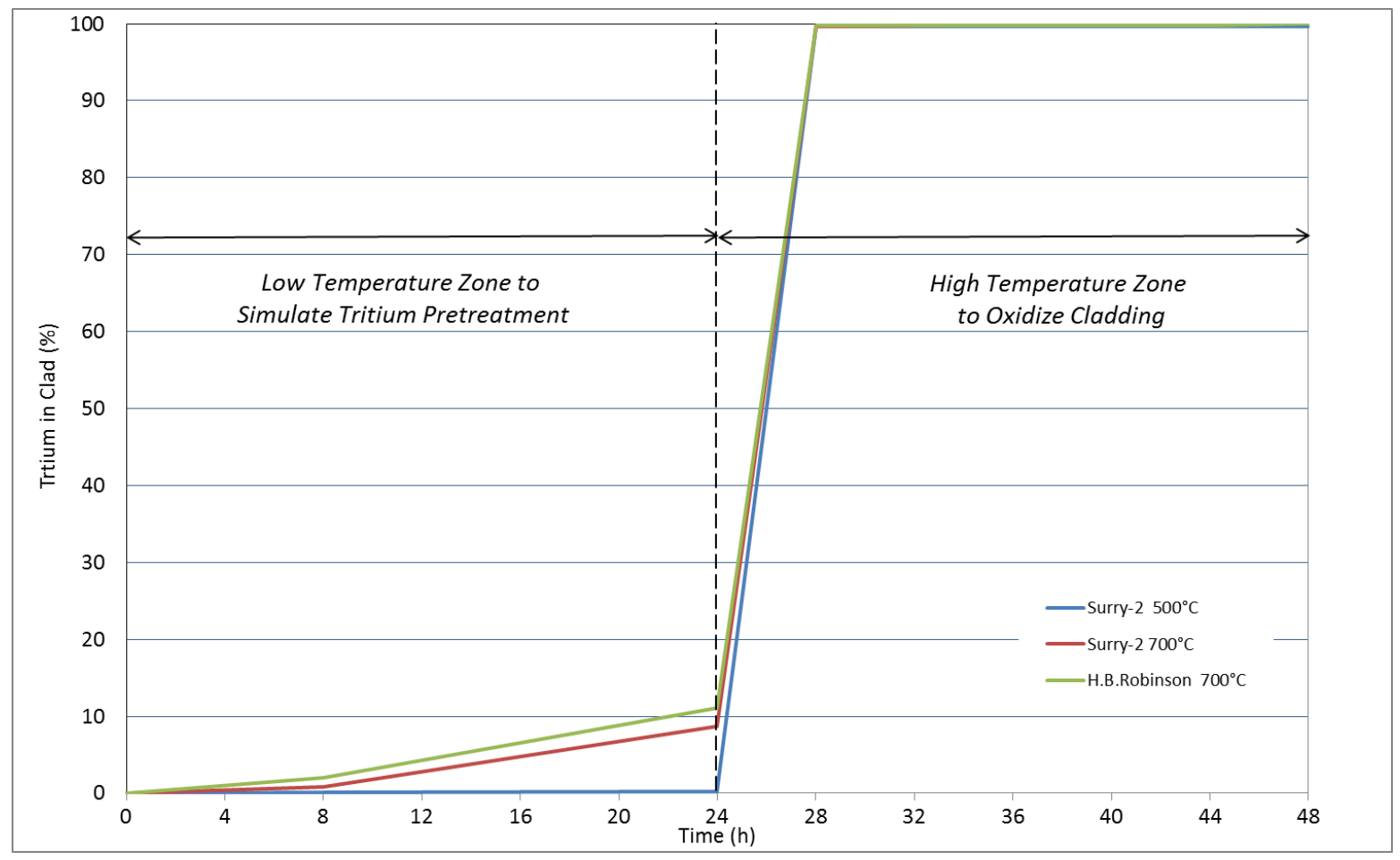

Fig. 2. Tritium released as a function of heating time and temperature: low-temperature for $24 \mathrm{~h}$.

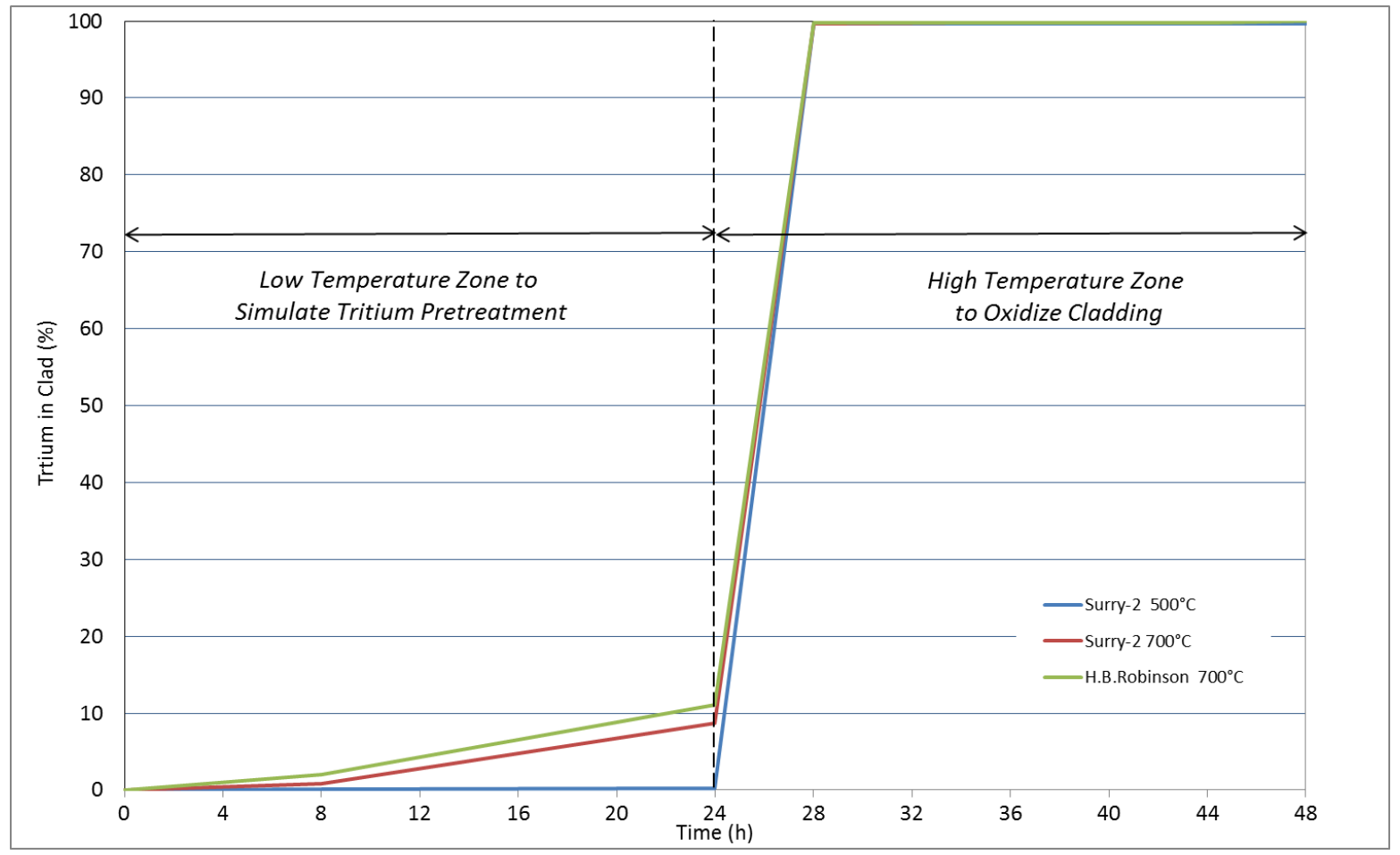

Fig. 3. Tritium released as a function of heating time and temperature: low-temperature for $96 \mathrm{~h}$. 


\section{SUMMARY/CONCLUSIONS}

Test results for tritium in Surry-2 and H.B. Robinson PWR cladding indicate that the cladding that received no heat treatment had a tritium concentration of $\sim 235$ and $500 \mu \mathrm{Ci} / \mathrm{g}$, respectively. The average total tritium found in the cladding samples varied less than $15 \%$ between the samples. The data indicate that $<20 \%$ of the tritium in PWR cladding will be removed by pretreatment at $500-700^{\circ} \mathrm{C}$ for $24 \mathrm{~h}$. Essentially $100 \%$ of the tritium is released if the heating time at $700^{\circ} \mathrm{C}$ is extended to $96 \mathrm{~h}$. Small amounts of tritium are expected to be released if the cladding is heated at $\leq 600^{\circ} \mathrm{C}$ for up to $96 \mathrm{~h}$.

These data indicate that the amount of tritium released from tritium pretreatment systems will be dependent on both the operating temperature and length of time in the pretreatment system. Under certain conditions, a significant fraction of the tritium could remain bound in the cladding and would need to be considered in any subsequent processing of the cladding to recover/recycle the zirconium.

\section{REFERENCES}

1. S. Robinson et al., Review of Tritium in Zircaloy Cladding from Liquid Water Reactors, FCRD-SWF-2013-000288, UT-Battelle LLC, Oak Ridge National Laboratory, August 2013.

2. S. Robinson et al., Evaluation of Tritium Content and Release from Surry-2 Fuel Cladding, FCRD-SWF-2014-000417, UT-Battelle LLC, Oak Ridge National Laboratory, September 2014. 